\title{
Courses Affecting the Academic Performance of Students in Salalah College of Technology
}

\author{
Bernard Ugalde \\ Salalah College of Technology
}

\author{
Yashir Ambula \\ Salalah College of Technology
}

\author{
Allan Salburo \\ Salalah College of Technology
}

\begin{abstract}
This study is designed to investigate and determine the causes of academic failures and probation for Students of Salalah College of Technology during the academic year of 20172018. A descriptive approach was used in this study. Data gathering was conducted through analysis of student transcripts based on course classification, level, semester offerings as well as gender. It was observed that student failures commonly occur in English and Math courses for students in IT, Engineering and Business Departments. However, students in every specialization encounter difficulty on several specific courses, which this study was able to determine. The findings of this study are significant in identifying which courses to reinforce learning to help students in achieving better academic performance. Also, by identifying these courses, the college will be able to design and implement a more effective strategy for improving academic performances of its students.
\end{abstract}

\section{Keywords}

Academic Probation, Student Advising, Academic Performance of Students

\section{INTRODUCTION}

The number of student at Salalah College of Technology who are on academic probation has recently been on the rise according to the Probation Consultants Committee of the college. However, there are only limited formal studies conducted so far to determine what factors put students under academic probation. And yet, it was always been a concern both for management and academic advisors to devise plans and remedial actions how to help these students get out the probation. Therefore studies need to be undertaken to further investigate the factors contributing to academic probation.

According to the college bylaws, a full-time student who achieves less than 2.0 Grade Point Average (GPA) will be put under academic probation. In such cases, a student is required to take remedial actions, which may include course load reduction by limiting the number of credit hours in a regular semester, taking up a course that might help raise the GPA, or postponement to a subsequent semester. A documented scenario projection is prepared by the academic advisor from the Mark Management System (MMS) becomes mandatory before registering for the following semester. This will tell the minimum marks combination that the student will need to get in order for him to get out of probation.

In such cases, a student is required to take remedial actions, which may include course load reduction by limiting the number of credit hours to 12 in a regular semester, taking up a course that might help raise the GPA, or postponement to a subsequent semester. A documented scenario projection is prepared by the academic advisor from the Mark Management System (MMS) becomes mandatory before registering for the following semester. This will tell the minimum marks combination that the student will need to get in order for him to get out of probation. A student who fails to attain regular status in four consecutive semesters will result for dismissal from the college.

A number of studies have investigated some of the factors that may lead to probation status. There is considerable empirical research evidence in the literature that correlate academic advising, student retention and attrition. Authors typically imply academic probation students are underprepared for post-secondary education. These students lack commitment, self-discipline, and knowledge of institutional culture and expectations which are all salient features related to academic success. These studies also are largely focused on describing positive intervention strategies which has been implemented to assist this group of students like addressing the psychological difficulties Demetriiou [1] and Nance [2], encouraging student engagement Boretx [3], improving the ability to be responsible for their own learning Cherry and Coleman [4], and developing academic literacy course programs designed to assist students Royal and Tabor[5].

Though these various studies have been carried out to investigate the factors contributing to academic probation in many colleges and universities, such undertaking to analysis of students' transcript is first of its kind in Salalah College of Technology. The results of such a study would help management and academic advisors and to provide better advisory services.

The paper is organized to present the related literature in section 2, Section 3 presents the methodology of the study together with the result and findings of the research in section 4. Section 5 gives conclusion and recommendations. Section 7 and 8 present acknowledgment and references respectively.

\section{REVIEW OF RELATED LITERATURE}

Abundant evidence of research carried out on academic probation focused on probationary students' characteristics. Their lack of essential learning skills such as time management, problem-solving, studying, reading, goalsetting, note taking, mind-mapping and anxiety management are often stated as well (Heiligenstein, Eric, et al[6]; Trombley [7]; Damashek[8]).

Investigations comparing students on academic probation to students in good standing indicated that those on academic probation had significantly lower high school grade point averages, worked more, had children living with them more often, and expressed more obstacles to academic success than students in good standing (Tovar, and Merril [9]; Morisano, Dominique, et al. [10]; Trombley [7]). Interestingly, all groups reported similar academic skills problems, although students in jeopardy scored significantly lower on a standardized assessment of study skills, suggesting that they might not recognize the shortfalls of their study skills [10].

The literature also enumerates several impediments leading to academic probation. These include personal problems, time constraints, and lack of motivation [7]; procrastination, poor 
time management, inefficient study strategies, disorganization, and poor concentration [10]; poor preparation, employment, personal illness, being a caregiver, mental health issues (i.e., depression, stress, anxiety, and attention deficit disorders[9]); and difficulty to balance school, work, and home-related responsibilities, problematic personal relationships, and lack of connectedness to campus life [6]. In view of this literature, which promotes an oversimplified image of probationary students by focusing on their common characteristics, one study [8] emphasized that they do not form a homogenous group, highlighting the importance of studying probation.

Literature also centers on programs implemented to assist probationary students. Seeing as there are no policies or guidelines mandating the development of probationary programs[11] they vary greatly in terms of structure, format, and conceptual foundation (Miller and Patricia [12]; Martin, Don, et al.[13]; Des, Susan, and Redding[14]; Dery[15]; Martin, Don, et al.[16]; Hoover[17]). Literature on probationary programs offers a good step in the right direction by proposing new ways of assisting students. However, calling for development in the area, Utzman, Riddle, and Jewell[18] noted that research on the effectiveness of remedial programs is scarce, underfunded, and inconclusive.

The literature and studies presented above is mainly descriptive and generally relies on quantitative methodologies, focusing on characteristics of probationary students, reasons for being placed on academic probation, and programs implemented to assist students on probation.

\section{METHODOLOGY}

Student sample was derived using a matrix with a margin of error of $3 \%$ and confidence level of $95 \%$ from the total population of 350 students who are in Academic Probation 4 in Salalah College of Technology of AY 2017-2018. A total of 195 students were studied in this research. Courses in the students' transcript were analyzed based on course classification, level and semester offering. Gender of students was also classified.

\section{RESULTS AND FINDINGS}

Based on the study conducted, the 5 top courses for each level (Diploma 1 and Diploma 2) on the three academic departments are as follows:

\subsection{IT Department}

For IT Department, students in Diploma 1 are likely to fail in Technical Writing 1 and Introduction to Database in their 1st semester and on their 2nd semester, Managerial Statistics, Introduction to Database and Applied Database. Of these five courses, 2 are non-major courses, which have lower passing marks compared to major ones, and 2 of the remaining 3 are database courses. Finally, a basic programming course completes the list. Refer to table 1 below.
Table 1: Top 5 courses where most students FAIL in Diploma 1

\begin{tabular}{|c|c|c|c|}
\hline Rank & $\begin{array}{c}\text { Course } \\
\text { Code }\end{array}$ & Course Description & Hit \\
\hline 1 & $\begin{array}{c}\text { ENTW110 } \\
0\end{array}$ & Technical Writing I & 132 \\
\hline 2 & MATH1201 & Managerial Statistics & 102 \\
\hline 3 & ITSE1101 & $\begin{array}{c}\text { Introduction To } \\
\text { Programming (Using C++) }\end{array}$ & 94 \\
\hline 4 & ITDB1102 & Introduction To Database & 92 \\
\hline 5 & ITDB1204 & Applied Database & 91 \\
\hline
\end{tabular}

For Diploma 2 level, students are likely to fail, Calculus 1, a department requirement, Principles of Data Telecommunications, a major requirement, and three elective courses, Business Ethics, Introduction to Business and Fundamentals of Multimedia, as shown in Table 2.

Table 2: Top 5 courses where most students FAIL in Diploma 2

\begin{tabular}{|c|c|c|c|}
\hline Rank & $\begin{array}{c}\text { Course } \\
\text { Code }\end{array}$ & Course Description & Hit \\
\hline 1 & MATH1200 & Calculus I & 59 \\
\hline 2 & ITNT2201 & $\begin{array}{c}\text { Principles Of Data } \\
\text { Telecommunications }\end{array}$ & 54 \\
\hline 3 & PHIL3108 & Business Ethics & 53 \\
\hline 4 & BAMG1100 & Introduction To Business & 51 \\
\hline 5 & ITMM2200 & Fundamentals Of Multimedia & 50 \\
\hline
\end{tabular}

In summary, a total of 4 major requirements, a college requirement, 2 department requirements and 3 college electives that students usually fail.

Furthermore, the researchers found out that the top failing courses in IT Department are Technical Writing and Calculus, both of which are not major requirements. Since one of the top failing courses is Technical Writing 1, a course enrolled in the first semester of Diploma 1. It is observed that students fresh from the foundation are weak in the English Language. Comprehension is poor, thus affecting the learning capacity of these students. 


\subsection{Engineering Department}

In the Engineering Department, the Diploma 1 level courses are common. Students will then have to choose from 5 specializations after that, to wit, Mechanical, Electrical, Civil, Chemical and Architectural specializations.

In the Diploma level, as shown in Table 3, students are like to fail in Physics 1, Calculus1 and Computer for Engineering courses in their 2nd semester. These three courses have passing marks of 60 . Both Physics courses are also included in the top 5 courses that students fail. It is also interesting to note that in their 1st semester, students are having a hard time passing Technical Writing 1 which is the same case in the IT Department.

Table 3: Top 5 courses where most Students Fail in Diploma1

\begin{tabular}{|c|c|c|c|}
\hline Rank & $\begin{array}{c}\text { Course } \\
\text { Code }\end{array}$ & Course Description & Hit \\
\hline 1 & PHYS1100 & Physics 1 (Engineering) & 162 \\
\hline 2 & MATH1200 & Calculus I & 161 \\
\hline 3 & EECP1290 & $\begin{array}{c}\text { Computer Programming For } \\
\text { Engineering }\end{array}$ & 147 \\
\hline 4 & PHYS1211 & $\begin{array}{c}\text { Physics 2 (Engineering) } \\
143\end{array}$ \\
\hline 5 & ENTW1100 & Technical Writing I & 140 \\
\hline
\end{tabular}

In Mechanical Specialization, students most likely fail five courses in their 1st semester, 4 of these are major requirements: Engineering Materials, Electrical Technology, Applied Mechanics and Manufacturing Process. Again, Technical Communication, an English course, is included. Business Ethics is rank number 1, as shown in Table 4 below. Both Technical Communication and Business Ethics have a passing mark of 55 .

Table 4: Top 5 courses where most students FAIL in Mechanical

\begin{tabular}{|c|c|c|c|}
\hline Rank & $\begin{array}{c}\text { Course } \\
\text { Code }\end{array}$ & Course Description & Hit \\
\hline 1 & PHIL3108 & Business Ethics & 37 \\
\hline \multirow{2}{*}{2.5} & ENGL2100 & Technical Communication & 35 \\
\cline { 2 - 4 } & MIME2204 & Engineering Materials & 35 \\
\hline 4 & MIEE2110N & Electrical Technology & 32 \\
\hline \multirow{2}{*}{5.5} & MIME2101N & Applied Mechanics I & 30 \\
\cline { 2 - 4 } & MIME2130 & Manufacturing Process & 30 \\
\hline
\end{tabular}

Table 5: Top 5 courses where most student FAIL in Electrical

\begin{tabular}{|c|c|c|c|}
\hline Rank & $\begin{array}{c}\text { Course } \\
\text { Code }\end{array}$ & Course Description & Hit \\
\hline 1 & EEPW2150 & Electrical Principles & 19 \\
\hline 2 & PHIL3108 & Business Ethics & 16 \\
\hline 3 & EETE2102 & Electronics I & 15 \\
\hline \multirow{2}{*}{4} & MATH2100N & Calculus I I & 14 \\
\cline { 2 - 4 } & ENGL2100 & Technical Communication & 14 \\
\hline
\end{tabular}

In Electrical Specialization, 4 of the five courses registered in the 1st semester are difficult for the students namely, Electrical Principles, Business Ethics, Electronics 1 and Calculus 1. The fifth course is again, Technical Communication, an English course. Of these five courses, 2 are major requirements, 2 are college requirements and one department requirement, as shown in Table 5.

In Civil Specialization, 4 out of the five courses in registered semester one are most likely to fail. These courses are Calculus II, Engineering Survey, Materials and Methods of Construction as well as Technical Communication. The two courses in the 2nd semester are Building Drawing and Business Ethics. Refer to Table 6 below.

Table 6: Top 5 courses where Students FAIL in Civil

\begin{tabular}{|c|c|c|c|}
\hline Rank & $\begin{array}{l}\text { Course } \\
\text { Code }\end{array}$ & Course Description & Hit \\
\hline \multirow{2}{*}{1.5} & MATH2100N & Calculus I I & 17 \\
\hline & CELS2100 & Engineering Surveying & 17 \\
\hline 3 & $\mathrm{ARCH} 2120$ & $\begin{array}{l}\text { Materials And Methods Of } \\
\text { Construction }\end{array}$ & 16 \\
\hline \multirow{3}{*}{5} & ENGL2100 & Technical Communication & 12 \\
\hline & CECE2235 & Building Drawing & 12 \\
\hline & PHIL3108 & Business Ethics & 12 \\
\hline
\end{tabular}

In Chemical Specialization, 4 out of the five courses registered in semester one are most likely to fail. Three of these courses are major requirements, Engineering Thermodynamics, Organic Chemistry, and General Chemistry. Calculus II is a department requirement and is also registered in Semester 1. Business Ethics is the 5th course and is registered during Semester 3. Take note that students are having difficulties in both chemistry courses. Refer to Table 7 below. 
Table 7: Top 5 courses where Students FAIL in Chemical

\begin{tabular}{|c|c|c|c|}
\hline Rank & $\begin{array}{c}\text { Course } \\
\text { Code }\end{array}$ & Course Description & Hit \\
\hline 1 & CHEE2101 & $\begin{array}{c}\text { Engineering } \\
\text { Thermodynamics }\end{array}$ & 5 \\
\hline 2 & CHEM2101 & Organic Chemistry & 3 \\
\hline 3 & CHEM2100 & General Chemistry & 2 \\
\hline 4 & MATH2100N & Calculus I I & 2 \\
\hline 5 & PHIL3108 & Business Ethics & 2 \\
\hline
\end{tabular}

Table 8: Top 5 courses where Students FAIL in Architectural

\begin{tabular}{|c|c|c|c|}
\hline Rank & $\begin{array}{c}\text { Course } \\
\text { Code }\end{array}$ & Course Description & Hit \\
\hline 1 & ENGL2100 & Technical Communication & 8 \\
\hline 2 & CECE2110N & Applied Mechanics C & 6 \\
\hline 3 & ARCH2130 & Architecture And Society & 5 \\
\hline \multirow{2}{*}{5} & ARCH2100 & Visual Communication 1 & 4 \\
\cline { 2 - 4 } & ARCH2110 & Architectural Workshop & 4 \\
\cline { 2 - 4 } & CECE2220 & Theory Of Structure 1 & 4 \\
\hline
\end{tabular}

In Architectural Specialization, as shown in Table 8, all of the courses registered in semester 1 are most likely to fail, to wit, Technical Communication, Applied Mechanics C, Architecture and Society, Visual Communication and Architectural Workshop. Theory of Structure makes up the list. Of these six courses, 5 are major requirements. Rank 1 is an English course, Technical Communication.

In summary, for the major requirements, a total of 17 courses where students are having difficulty in passing, 7 for both college requirements and department requirements and finally two electives.

Moreover, for the Engineering Department, the top failing course for Diploma is Physic 1. For the specialization, Business Ethics for Mechanical, Electrical Principle for Electrical, Calculus II for Civil, Engineering Thermodynamics for Chemical and Technical Communication for Architectural Engineering.

\subsection{Business Studies Department}

In the Business Department, Diploma 1 courses are common, and students have to choose specialization after that. Specialization to choose from is Accounting, HRM, and Marketing.
For the Diploma 1 level, the top failing course is Technical Writing 1, an English course, followed by four department requirement courses: Principles of Accounting, Introduction to Business, Principles of Management and Principles of Marketing. Three of these courses are in Semester 1 and two courses in Semester, as indicated in Table 9.

Table 9: Top 5 courses where most students FAIL in Diploma 1

\begin{tabular}{|c|c|c|c|}
\hline Rank & $\begin{array}{c}\text { Course } \\
\text { Code }\end{array}$ & Course Description & Hit \\
\hline 1 & ENTW1100 & Technical Writing I & 98 \\
\hline 2 & BAAC1102 & Principles Of Accounting & 93 \\
\hline 3 & BAMG1100 & Introduction To Business & 87 \\
\hline 4 & BAMG1207 & Principles Of Management & 86 \\
\hline 5 & BAMK1205 & Principles Of Marketing & 74 \\
\hline
\end{tabular}

For Accounting Specialization, there are eight courses identified where students are having difficulties. The top failing course is Financial Management, followed by Entrepreneurship, Principles of Accounting, Auditing and Control 1, Principles of Macroeconomics, Introduction to Web Technology, Intermediate Accounting 1 and Business Ethics. Three of these courses are registered in Semester 1, three courses in Semester 2 and two courses in Semester 3. Principles of Accounting 2, a major requirement, is considered to be the hardest course in this specialization according to the students. It is also interesting to note that though Entrepreneurship is a business course, students are struggling to pass the said course. English course is not present. See Table 10 for details.

Table 10: Top 5 courses where most students FAIL in ACCOUNTING

\begin{tabular}{|c|c|c|c|}
\hline Rank & $\begin{array}{c}\text { Course } \\
\text { Code }\end{array}$ & Course Description & Hit \\
\hline 1 & BAFI2109 & Financial Management & 7 \\
\hline \multirow{2}{*}{2.5} & BAMG2111 & Entrepreneurship & 6 \\
\cline { 2 - 4 } & BAAC2100 & Principles Of Accounting -2 & 6 \\
\hline 4 & BAAC2203 & Auditing \&Control -1 & 4 \\
\hline \multirow{2}{*}{6.5} & BAEC2204 & $\begin{array}{r}\text { Mrinciples Of } \\
\text { Macroeconomics }\end{array}$ & 2 \\
\cline { 2 - 4 } & ITSE1203 & $\begin{array}{r}\text { Introduction To Web } \\
\text { Technology }\end{array}$ & 2 \\
\cline { 2 - 4 } & BAAC2206 & Intermediate Accounting -1 & 2 \\
\cline { 2 - 4 } & PHIL3108 & Business Ethics & 2 \\
\hline
\end{tabular}


For HRM Specialization, Introduction to Web Technology, a college elective, is the top failing course which is registered on Semester 3. Database for Small Business, rank 5, is also on the same Semester. Financial Institutions and Services, Compensation and Benefits as well as Business Ethics are registered on Semester 2. It is noteworthy that students don't have difficulty in Semester 1 courses and English courses are not included. Details can be found in Table 11 below.

Table 11: Top 5 courses where most students FAIL in HRM

\begin{tabular}{|c|c|c|c|}
\hline Rank & $\begin{array}{c}\text { Course } \\
\text { Code }\end{array}$ & Course Description & Hit \\
\hline 1 & ITSE1203 & $\begin{array}{c}\text { Introduction To Web } \\
\text { Technology }\end{array}$ & 10 \\
\hline 2.5 & BAFI2210 & $\begin{array}{c}\text { Financial Institutions And } \\
\text { Services }\end{array}$ & 8 \\
\cline { 2 - 4 } & BAHR2204 & Compensation And Benefits & 8 \\
\hline 4 & PHIL3108 & Business Ethics & 7 \\
\hline 5 & BADB2301 & Database For Small Business & 7 \\
\hline
\end{tabular}

Table 12: Top 5 courses where most students FAIL in MARKETING

\begin{tabular}{|c|c|c|c|}
\hline Rank & $\begin{array}{c}\text { Course } \\
\text { Code }\end{array}$ & Course Description & Hit \\
\hline 1 & BAFI2109 & Financial Management & 8 \\
\hline 2 & BAMG2111 & Entrepreneurship & 6 \\
\hline 3 & PHIL3108 & Business Ethics & 5 \\
\hline 4 & BAMK2204 & Retail Management & 4 \\
\hline 5 & BAMK2101 & Principles Of Retailing & 3 \\
\cline { 2 - 4 } & BAMK2100 & Principles Of Sales & 3 \\
\cline { 2 - 4 } & BAMK2203 & Sales Management & 3 \\
\hline
\end{tabular}

For Marketing Specialization, there are seven identified courses of which Financial Management, a department requirement, is the top failing course in Semester 1 together with Entrepreneurship, Principles of Retailing and Principles of Sales. 4 courses in Semester 1 have a high failure rate. There are 3 Semester 2 courses, namely, Business Ethics, Retail Management, and Sales Management. Most of these courses are major requirements. Like in the Accounting and HRM specialization, no English course was identified. Refer to Table 12 .

In summary, there are eight major requirements, six college requirements, nine department requirements, and two college electives courses that students are having trouble with.
Furthermore, for the Business Department's top failing course per level, Technical Writing 1 is rank 1 for Diploma 1

\section{CONCLUSION}

In conclusion, most of the dismissal cases due to probation are during the First-Year Diploma level. These students most likely fail on almost all of their registered courses in a given semester during the abovementioned level. It is noteworthy that the top failing course in IT and Business Diploma is Technical Writing I, a non-major course. In Engineering Diploma, the top failing course is Physics 1 .

The researchers highly recommend that these observations and findings be passed on to each department and its concerned sections for them to be able to review and possibly improve their course delivery, assessments, course management and other course-related activities to minimize if not eliminate dismissal of students due to probation.

\section{ACKNOWLEDGMENTS}

The authors wish to thank Salalah College of Technology, Oman for the wonderful opportunity and continuing support on this kind of work.

\section{REFERENCES}

[1] Demetriou, Cynthia. "The attribution theory of learning and advising students on academic probation." NACADA journal31.2 (2011): 16-21.

[2] Nance, Molly. "The psychological impact of academic probation." Diverse Issues in Higher Education 24.19 (2007): 12 .

[3] Boretz, Elizabeth. "Midsemester academic interventions in a student-centered research university." Journal of College Reading and Learning 42.2 (2012): 90-108.

[4] Cherry, Lynn, and Lindy Coleman. "A Plan for Academic Success: Helping Academically Dismissed Students Achieve Their Goals." Learning Assistance Review 15.2 (2010): 21-32.

[5] Royal, Kenneth D., and Alison J. Tabor. "Theories of Student Success: Evaluating the Effectiveness of an Intervention Strategy." Online Submission (2008).

[6] Heiligenstein, Eric, et al. "Psychological and academic functioning in college students with attention deficit hyperactivity disorder." Journal of American College Health47.4 (1999): 181-185.

[7] Trombley, Cherine M. "Evaluating students on probation and determining intervention strategies: A comparison of probation and good standing students." Journal of College Student Retention: Research, Theory \& Practice 2.3 (2000): 239-251.

[8] Damashek, Richard. "Support Programs for Students on Academic Probation." (2003).

[9] Tovar, Esau, and Merril A. Simon. "Academic probation as a dangerous opportunity: Factors influencing diverse college students' success." Community College Journal of Research and Practice 30.7 (2006): 547-564.

[10] Morisano, Dominique, et al. "Setting, elaborating, and reflecting on personal goals improves academic performance." Journal of Applied Psychology 95.2 (2010): 255.

[11] Hutson, Bryant L. Monitoring for success: Implementing a proactive probation program for diverse, at-risk college 
students. Diss. University of North Carolina at Greensboro, 2006.

[12] Miller, Doris Metzger, and Patricia O'Connor. "Achiever personality and academic success among disadvantaged college students." Journal of Social Issues 25.3 (1969): 103-116.

[13] Martin, Don, et al. "Increasing prosocial behavior and academic achievement among adolescent African American males." Adolescence 42.168 (2007).

[14] Des Ormeaux, Susan, and Evelyn A. Redding. "GAIN: A successful recruitment and retention program for disadvantaged students." Journal of Nursing Education 29.9 (1990): 412-414.
[15] Dery, Bonnie. An examination of intervention programs for students on academic probation. Diss. State University of New York Empire State College, 2009.

[16] Martin, Don, et al. "Increasing prosocial behavior and academic achievement among adolescent African American males." Adolescence 42.168 (2007).

[17] Hoover, Charlotte. "The Purpose and Practice of Academic Probation." (2014).

[18] Utzman, Ralph R., Daniel L. Riddle, and Dianne V. Jewell. "Use of demographic and quantitative admissions data to predict academic difficulty among professional physical therapist students." Physical therapy 87.9 (2007): 1164-1180. 